\title{
The influence of Greek drama on Matthew's Gospel
}

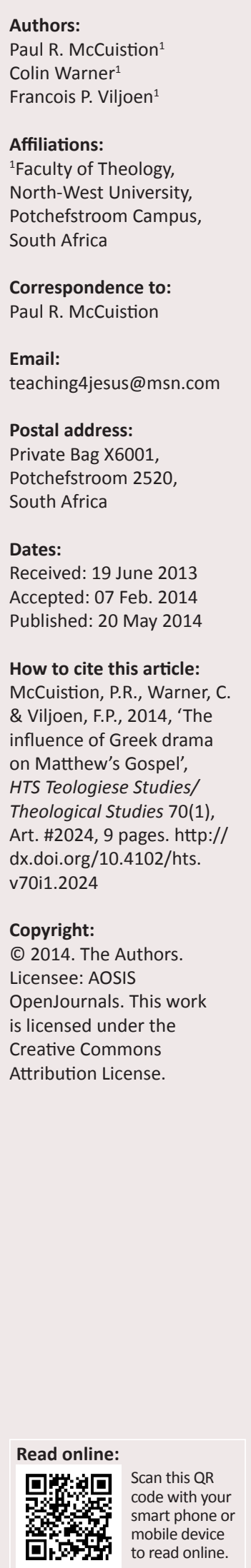

This article presents the Greek influence on the genre of Matthew's text. Greek and Roman tragedy is examined, from which the five basic elements of tragedy are identified. A brief examination of the characters in the Matthean text is done to identify Greek cultural influences on the structuring of the Gospel. This study offers evidence that Matthew may have intentionally orchestrated a drama with the intent of having an understandable, attractive way to present Jesus to Jew and gentile alike.

\section{Introduction}

Matthew's Jewishness is a matter of much debate. Nonetheless, it is the most fertile of the Gospels for discovering the relationship between the Hebrew ideal of covenant and the Christological understanding of the reign of heaven. The primary reason is Matthew's Gospel is dominated by a structure that provides, for the most part, a Jewish viewpoint for his work. Guthrie (1990:32) maintains that this dominance is realised in the Old Testament citations and allusions that must obviously be a prime consideration in discussing the author's purpose. However, scholarship as a whole does not agree with the Jewish influence of the Gospel. The debate regarding the Jewishness of Matthew ranges from a true respect for Judaism where Jesus' teachings mirror their law, 'making Matthew the most Jewish of the Gospels' (Elliott 1992:359) to Matthew as an anti-Jewish Gospel that rewrites Mark, allegorises the key parables, and gives the commission to evangelise gentiles, not Jews (Cook 2008:192-202). The Gospel is, nevertheless, Jewish in orientation in order that the author can support his opening statement (Mt 1:1) and its ramifications, especially in relationship to $\pi \lambda \eta \rho$ ó $\omega$ [fulfil].

An important question in Matthean studies is: How does he use $\pi \lambda \eta \rho{ }^{\prime} \omega$ to demonstrate that Jesus' nature satisfies the Christological design for the prototype apostle who introduces the reign of heaven as the new covenant community? The idea of Jesus as the prototype apostle is a description of Jesus based on Hebrews 3:1, where he is called the 'Apostle of our confession'. It signifies that he is the first of those authoritatively sent from the Father as part of the New Covenant or Kingdom. Matthew's Jesus comes preaching the Kingdom as the first amongst many who proclaim the good news. Thus, he becomes the prototype for all to follow. However, before an examination of use of $\pi \lambda \eta \rho$ ó $\omega$, preliminary steps must be taken to clarify the fundamental nature of the Gospel. This article will examine one of these steps - the cultural influence that contributed to the author/compiler/editor's presentation.

The purpose of this article is to present the Greek influence on the genre of Matthew's text. Firstly, there will be an examination of Greek and Roman tragedy, followed by the elements of tragedy. Finally, a brief examination of the characters will be provided. Methodology will include historical-critical examination of these elements.

\section{Cultural influences}

Dunn (2005:43-44) is adamant about the nature of oral transition of the traditions of the Gospels, maintaining that the traditions formed some of the beliefs and identity of the early church. He says this in response to recent works regarding the place of memory in the transition of oral tradition. He contends that the work is flawed because some scholars (who he does not name) contend that the memory is casual and not group memory. He fears that this does not take into consideration the personal impact of Jesus on his followers, who would have greatly valued the accounts with which they were familiar. Included in Dunn's misgivings about memory studies is what is termed 'social' or 'cultural' memory that he feels is more creative than retentive (both italics are Dunn's emphasis). His contention is that, in a culture where oral tradition was propagated by trained mnemonic devices that protected the information ensuring 'the preservation of memories important to these groups, the dynamic of memory was bound to be different'. 
Whilst Dunn's arguments may seem convincing, one must never deny the cultural Sitz im Leben that prompt the need for the mnemonic devices. Matthew's broader Sitz im Leben is found in two cultural arenas - Greek and Hebrew. Both of these have means of transmitting important information. Exploration of these means will disclose the structure and purpose Matthew chose for his defence of the premise that Jesus is the Christ, son of David, son of Abraham.

This article will discuss the Greek influence on Matthew's Gospel. It would seem necessary to defend this in light of Matthew's apparent Jewishness. The reason for this order is that Matthew's audience, no matter their location (which, of course, is a matter of dispute), cannot avoid the secular influences unless they have cloistered themselves as the Qumran community did. Stanton (1993:91-98) suggests this as a possibility with his comparison of Matthew's work with the Damascus Document. If this is true, then the community may have been able to avoid the influence of Hellenism. If not, the secular influence of Athens would be unavoidable. Even in Palestine, the influence would be obvious. Stanton (ibid:113) suggests three influences on the Matthean community: (1) it a diverse element of Judaism, (2) it is a split from Judaism, or (3) it is a Christian community dominated by gentiles. This supports the possibility that the Hellenistic influences may have had inroads into the church.

Even if it is true that there was a Hellenistic influence, why study it? It is the contention of this study that Matthew used a familiar literary medium to outline his work, giving a popular format for an unusual story. The format of the Greek theatre provides such an outline. It is not even necessary that his community be familiar with it. It is necessary only for Matthew (or the editor[s]) to be familiar. Additionally, if there is a gentile concern, either because there are gentiles in the church or there is the desire to reach gentiles, then this format would give Matthew a common ground with them to tell the story of Jesus. Matthew's outline provides a way of dramatising the conflict between Jesus and the Pharisees who are used by Matthew to represent the covenant community. The drama presented by this conflict emphasises Matthew's Christological claim, giving Jesus kingdom authority to represent God in the new covenant.

\section{Greek influence - Genre of the text}

Greek culture is the first source for the consideration of Matthean structure. However, this is not found primarily in Platonic propositions or Aristotelian dialectics. Rather, the influence is found in Greek tragedy. The reason to begin here lies in the accepted fact that Matthew is a story. Kingsbury (1988:1-2) maintains that Matthew is a unified narrative or 'artistic whole'. The plot logically unites action, thought, and characters.

This work contends that Matthew's 'evaluative point of view' is in 1:1 - Jesus the Christ, son of David, son of Abraham. Whether this is viewed as the title to the book or the introduction to the first section of Matthew, it is obvious that this phrase lies at the heart of the kingdom message and Matthean purpose (cf. Kingsbury 1988:19-20). This simple phrase condenses the context, showing Jesus as the Christ (Christology), son of David (Kingdom), son of Abraham (Covenant).

Matthew takes these vital Jewish issues and clothes them in such a way as to have appeal to the Hellenised Jew, synthesising with his new culture and the non-Jew of that culture. What better way than to appeal to human drama? Thus, Matthew's story of Jesus appears to be one of tragedy as mounting tension against Jesus increases, popularity wanes, and his message of the kingdom is ignored. It is not until the exode [exit ode] of the Resurrection and ascension that there is a victorious turn. Regarding the miracle narratives of Matthew 8-9, Pasala (2008:299) proposes that there is a dramatic structure in the arrangement of the miracle narratives. Using the Aristotelian definition of tragedy, he divides Matthew 8-9 into three parts, creating a drama that clarifies the Gospel. This article contends that, what Pasala attempts to do for chapters 8-9, may be done for the entire book, providing a basis for the structure. This approach is justifiable in that Matthew is story; it is narrative. Pasala (ibid:13) confirms that text is a 'linear set of signs' between author and reader designed for communication. This results in the Gospel being unique and dynamic.

Thus, it is justifiable to look to this literary genre to find one of those meanings and, more importantly, the structure for Matthew's Gospel. Risley (2009) gives an excellent examination of drama, the theatre, and its application to Luke as the probable genre of literature.

\section{Greek tragedy}

In order to see the similarities between Greek tragedy and Matthew's Gospel, it is necessary to examine the basic makeup of Greek tragedy. The best starting place will be at the theatre because the theatre represented life in the form of tragedy and comedy. Tragedy normally dealt with heroic legend played out in the dilemma of noble families. It was usually set in a quasi-historical time (within two generations on either side of the Trojan War). For the Greek, this was a time 'when gods took a more direct interest in human affairs' (Csapo \& Slater 2005). Similarly, Matthew's tragedy followed Jesus, the son of David, the royal family of Israel. Matthew's lack of interest in chronology would make the setting quasi-historical. Blomberg (2001:23-24) suggests that looking at the Gospels in any synoptic harmony would easily recognise that the work is not chronologically motivated. Stein (2001:24) provides a helpful introduction to the history of the development of synoptic harmonies, noting that what he calls the first 'pure' synopsis should be credited to Johann Jacob Griesbach in 1776, in which Griesbach states in his introduction that he doubts that a harmonious narrative is possible for the chronological arrangement of the pericopes of the Gospels. Obviously, Matthew demonstrates God's involvement. He does this through his use of the Old Testament (OT) prophetic message that demonstrates 
involvement stretching from Israel's exilic setting through Matthew's contemporary situation.

Further, Greek tragedy was closely associated with religion. The stories were based on myth or history but had varied interpretation of the events that leaned toward idealisation (Trumbull 2007). Matthew's tragic story of an expectant, messianic hopeful emphasises the strained relationship evident between his various antagonists and the dynamic apostle of the new order. Matthew's drama elevated Jesus to the heroic stance of God's son as sacrificed herald (kerux) of the kingdom message. Such stories about heroes and gods were at the heart of drama (Webster 2004) that portrays the downfall of the hero, usually influenced by fate, human imperfections, or nature.

Joseph Campbell (1988:123) contends that the usual hero adventure begins with the loss of something of value (such as childhood at puberty when youth is lost and adulthood begins). His adventure is to regain that which was lost. Jesus' stated mission was to the 'lost house of Israel' (Mt 15:24; cf. 10:6, where Jesus sends his disciples to Israel rather than the gentiles). Unfortunately, the hero does not always win, especially if controlled by fate (moira). Campbell (1968:25-26) further notes that Greek tragedy celebrates the mystery of dismemberment: 'The happy ending is scorned as a misrepresentation ... yields but one ending: death, disintegration, dismemberment, and the crucifixion of the heart ...' However, unlike Greek tragedy and Campbell's hero, Matthew celebrates the victorious resurrection, with the hero returning home, fully satisfied. On the other hand, much like that to which the world is accustomed, Matthew's victorious message was not overwhelmingly accepted, since no one had seen anything like this before (chief priests and elders in 28:11-15 and some of the disciples in 28:17).

\section{Jewish connection to the Greek theatre}

Herod the Great introduced the theatre to Jerusalem. Jews objected to the decorations of the theatre. There is no indication that they objected to the idea of theatre. Outside Palestine, the acceptance of the theatre was greater. Philo was known to frequent the theatre (Barclay 1996:161; Free 1999:150). Additionally, archaeology supports the presence of Jews at the theatre. Barclay (1996:237-238) discusses the possibility of a structure at Berenice which was either an amphitheatre supported by the local Jews or a Jewish building used by them for political meetings. Showing Jewish participation in the theatre are two inscriptions indicating reserved seating. One is in Miletus where there is an inscription that reads,

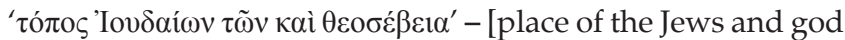
fearers] (Deissman 1910:446). The inscription is located on good seating, in the fifth row. This inscription dates from the late second or early third century. The second is in the odeum at Aphrodisias in Caria (Goranson 2007:363-364).

\section{Greek or Roman biography}

This raises the question of whether Matthew's account draws from Greek tragedy giving us a tragic story with a hero, plot, and antagonist, or whether the similarities are too few to have an influence on his structure. This question is raised in light of the fact that many would agree that the acceptable form of Matthew's Gospel is that of biography, which is another genre of story (Aune 1987:17-76; Blomberg 2001:45-46; Nolland 2005:19; Shuler 1982:54; Weber 2000:10). However, some would think that writing a biography was not Matthew's purpose (Hendriksen \& Kistemaker 19532001:710-711; Gardner 1991:421; Utley 2000:28, 34; Walvoord, Zuck \& Dallas Theological Seminary 1985:96, 268).

Blomberg (2001:45-46) suggests that Matthew's Gospel 'measures up quite well when compared with ancient Jewish and Greco-Roman histories and biographies'. He does not say, either quantitatively or qualitatively, how they 'measure up'. Thus, it is necessary to define what is meant by biography. In Burridge's (1995:59) comparison of the Gospels to GreekRoman biography, he prefers to use the term 'Lives' [bios]. He notes that the word biography does not even appear until the 5th century AD but was 'only preserved by the ninth-century writer, Photius'. Momigliano (1971:12) notes that during the Hellenistic age and beyond, 'Lives' [bios] (Greek) or [vitae] (Latin) was the most popular description. An example of this would be in Plutarch's Alexander where he writes, 'oute gàr historías gráphomen, állá bious' [For it is not Histories that I am writing, but Lives] (Alex., 1.2). Burridge (1995) notes that Plutarch attempts to distinguish historía from bios, by stating that history is:

concerned for the famous actions and illustrious deeds of men and for great events like sieges or battles; bios is interested in men's character, which may be revealed by little literary evidences like the odd phrase or jest. (p. 61)

Notably, Plutarch's distinction between historía and bios comes about one-third of the way through his book. This raises question regarding his reasons. Baldwin (1979:103) and Russell (1972:115-116) conclude that his subject matter was just too broad to cover every detail.

Geiger (1985:12-15), criticising Momigliano's definition of biography as the account of a man's life from birth to death, considers it futile to attempt the reconstruction of ancient literary theory, suggesting that the use of modern conceptions is preferred. Thus, he prefers the definition offered by the Oxford English dictionary: 'the history of the lives of individual men, as a branch of literature'. Burridge (1995:60) states that Momigliano's definition is not profound, but has the merit that it excludes dictating how biography is to be written. Furthermore, he notes that the definitions of Talbert (1993:714-715) and Aune (1987:9-60) assert that biography must be prose narrative and include purpose and historicity. From this, he concludes that there is a distinction between biographical elements found in various literary forms and literary form devoted to biography.

The question raised is whether Matthew's Gospel is a biography or a Greek drama. As indicated above, this may not be an easy decision. It can certainly be admitted that there are biographical features like those of Matthew's 
contemporaries. However, the greater question is what drives the structure, since this will help us better identify Matthew's context. Nolland (2005:20-22) suggests that the reader must consider what Matthew may have intended by his gospel. He concludes that Matthew may have understood his work as foundational. Thus, Matthew's community as well as future church communities would feel the need to return again and again to this book as a catechetical tool. Of interest is that Nolland (2005:22) questions whether the Gospel could be seen as a performance. He suggests that the story line is very strong, perhaps like the Greek drama that has been discussed. However, the extended discourses of Jesus present a problem for him in this regard, creating the need for other ways of relating.

The discourses do not need to be problematic. The structure of the theatre easily handles this difficulty, as will be revealed with an examination of the structure of tragedy in the Greek theatre. This argues that Matthew's structure and character analysis resembles Greek tragedy, making it more understandable for the common (koine) audience. Additionally, the character analysis will demonstrate a second cultural influence that drives the structure. Furthermore, Greek drama was based on history, thus, emphasising the character's search for meaning (Robinson 2002) or evidence of their psychological and ethical attributes (Trumbull 2007). Thus, Greek drama would support the literary genre of either historías from bios. To begin, it is necessary to examine the theatre.

\section{Elements of Greek tragedy}

Greek tragedy has five basic elements. These are Prologue, Parodos, Episode, Stasimon, and Exodos. Matthew's structure uses five literary markers of Kai egéneto hote etélesen ho Iēsous [And when Jesus finished] $(7: 28 ; 11: 1 ; 13: 53 ; 19: 1 ; 26: 1)$ to move from episode to episode after introducing his primary character, Jesus. Table 1 is a comparison of a Greek tragedy to Matthew.
The Episode/Stasimon (with or without the Epode) are repeated as often as necessary to support the play. The number of episodes fluctuates. MacLennan (1999) determines the norm to be three to five and Csapo and Slater (2005) number them from four to six. The episodes involve both the chorus and the actors (Englert 2012). Matthew's five literary markers divide the episode/stasimon into five narratives, followed by five discourses, which follows the structure of the tragedy.

If, following Luz (2005:23), it is accepted that Matthew compiled the discourses given at different times and in different settings, then this could mimic the episode/stasimon structure nicely.

Sophocles's (2010) Ajax provides an example of how the play is organised and allows us to view the similarities with Matthew. The prologue is between the hero, Odysseus and the goddess Athena. Their dialogue has Athena advising Odysseus regarding his primary opponent Ajax, who was considered the finest warrior, second only to Achilles. The play is set the day after the decision is made to award Odysseus the armour and weapons of Achilles, who was killed in battle. The introductory dialogue has Athena telling how she rescued Odysseus from Ajax's attempts on his life. She states that she turned his anger against Odysseus and toward some sheep and cattle. (This reminds us of the instance where Jesus cast demons into swine [Mt 8:30-32].) Athena encourages Odysseus, assuring him of her favour by complimenting him, 'Like a keen-nosed Spartan hunting dog your path is taking you straight to your goal' (Sophocles 2010:9-10).

In Matthew's prologue, the stage is being set for the introduction of the hero. This hero is praised via his genealogy and the circumstances of his birth. The prologue continues with the hero forced to go to Egypt and return to Nazareth. Thus, both prologues set up the hero and their

TABLE 1: Comparison of the structure of a Greek tragedy and Matthew.

\begin{tabular}{ll}
\hline Element & Greek drama \\
\hline Prologue & $\begin{array}{l}\text { The prologue presents the primary topic } \\
\text { and gives the mythological back-ground } \\
\text { needed to under-stand the play. }\end{array}$ \\
Parodos & $\begin{array}{l}\text { The entry song of the chorus. This helps } \\
\text { set the stage for the episodes. }\end{array}$
\end{tabular}

Matthew's structure

Jesus the Messiah, son of David, son of Abraham is the topic. The genealogy provides the background (1:1-17). Additionally, the birth account establishes the metaphysical background.

Matthew holds the position of chorus in the Gospel. Amongst other things, the chorus provided for scene changes, offer important background and summary information that facilitate an audience's ability to follow the story, and offer commentary about and underline main themes animating the action (Wiemelt n.d.). The purpose of the chorus was to depict the reaction of the people in the audience. Using narrative, the chorus gave necessary background information that helped the audience follow the plot. It also identified the reasons behind the extreme behaviour of the principle characters. One final function was to make observations or drew conclusions about the play (Stephens 2006).

Matthew's opening chorus further establishes the 'mythological' background by presenting the unusua events at Jesus' birth, introduction of the main character, viz-a-viz, his herald (John the Baptist), baptism, and temptation.

Parts of the Parodos Strophê [Turn], Antistrophê [Counter(MacLennan 1999)

Turn], and Epode [After-Song] These are used to depict the positioning of the chorus.

Episode Episode - Speeches and dialogues are typical in an episode (MacLennan 1999).

Stasimon Stasimon - Englert (2012) notes that (Stationary Song) the ode is a reflection of the episodes, the ode is a reflection of the episode
putting them into a larger context. After-song to the Episode/Stasimon

Epode given by the chorus.

Exodos The exit song that offers 'words of wisdom related to the actions and outcome of the play' (Englert 2012).
Matthew presents a turn and counter-turn of Jesus. Firstly, Jesus turns to the metaphysical battle for supremacy with Satan, only to turn back to his intended earthy mission. Matthew's Epode is in 4:17, where Jesus begins to preach his intended message. The second is in 16:21 when the scene is directed toward Jerusalem and the final act.

Matthew's five narrative sections contain movement, dialog, and other exchanges leading up to the discourse.

Kingsbury (1988:2-3) draws this distinction between story (what is told) and discourse (how it is told) Matthew's $(7: 29 ; 9: 8 ; 21: 27 ; 28: 18)$ dialogues reveal Matthew in the choral ode, responding to Jesus' actions or words.

The literary markers $(7: 28 ; 11: 1 ; 13: 53 ; 19: 1 ; 26: 1)$ are used to move from episode to episode.

Matthew's exit song is powerfully portrayed in the passion with the great crescendo of 'All authority has been given to Me in heaven and on earth; therefore, Go!' (28:18-19a). 
stories. Moreover, Burian and Shapiro (2008:81) inform us that the exchanges between the principal characters are the 'episodes', and the choral songs are the 'stasima'. This aligns perfectly with the narrative or discourse found in Matthew. In the narrative portions, the primaries (Jesus and Odysseus) are in conflict with an antagonist (the Devil - Mt 4:1-11 - and Ajax). Whilst the details of the dialogues that comprise the episodes are different in nature (Greek tragedy is intended to be set to music; Matthew may have been read), they both function in the same way. So it is with the stasima. Matthew's summary discourses are set in fashion to complete the stories that have led to them.

Burian and Shapiro (2008:82) also point out that in the first half of the play all but one of the choral stasima occur and that there is a 'dramatic heightening between a principal character, such as Tekmessa or Aias and the Chorus, who becomes a virtual second actor in the first part of the drama'. This same type of crescendo is obvious in Matthew, with Jesus building from the Sermon on the Mount to the parables of chapter 13. The break (13:53) gives Matthew the opportunity to make summary statements that complement the first peak of his plot: the law of the new covenant (Mt 5-7). This would seem to present a problem with the structure in that Jesus is the one delivering the discourses, whilst in Greek tragedy it is the chorus that has already been compared to Matthew. In reality, whilst Matthew puts these words on Jesus' lips, Matthew is the compiler or editor who is collecting sayings of Jesus made at various times during his ministry. Thus the chorus, Matthew, is singing a chorus of the collective sayings of Jesus as if Jesus himself is saying them. This becomes even more convincing when it is considered that the chorus had diminished by Matthew's day and the chorus leader becomes one of the actors (Foley 2010).

With these comparisons in place, the discussion can move to yet another Matthean reflection of two key elements of Greek theatre - storytelling and imitation (Stephens 2006). Matthew (as author, editor, or redactor) sings the exploits of the god or hero, Jesus. Chatman (1978:19) contributes to our understanding of this. Comparing poetics and linguistics, he insists that it is necessary to ask, 'What are the necessary components - and only those - of a narrative?' He concludes that the structuralist theory of narrative contains story, which is a chain of events and existents made up of characters with the items of the setting and discourse. Simply, the story is the 'what' and the discourse the 'how' (Chatman 1978).

Matthew uses five distinct episodes or discourses to build the plot of his story. Especially from a Jewish perspective, Matthew would certainly be tragic, since the heralded, messianic hero satisfies none of the normal expectations, is compassionate toward gentiles, and dies. If 1:1 were Matthew's thesis, then one would think the plot would be less tragic and dominated by a conquering hero. In Matthew's story, Jesus is assaulted immediately, in the prologue, setting a pace that is heightened as the story develops. In Poetics, Aristotle (350 BCE) defines tragedy in this way:
Tragedy, then, is an imitation of an action that is serious, complete, and of a certain magnitude; in language embellished with each kind of artistic ornament, the several kinds being found in separate parts of the play; in the form of action, not of narrative; through pity and fear effecting the proper purgation of these emotions. By 'language embellished,' I mean language into which rhythm, 'harmony' and song enter. By 'the several kinds in separate parts,' I mean, that some parts are rendered through the medium of verse alone, others again with the aid of song.

Certainly, Matthew would fit easily into Aristotle's idea of tragedy. Jesus and his antagonist actions reveal the tragedy. The soul of the tragedy is the plot (Aristotle $350 \mathrm{BCE}$ ). It is here that the characters develop; protagonist and antagonist rise up against each other in the form of actions that define both of these.

Furthermore, Aristotle determined that plot is the most important of all the structures, with character being second. Regarding plot, McManus (1999a) notes four qualities detailed by Aristotle. Firstly, plot is built around a beginning (incentive moment that starts the cause and effect), middle (climax that is caused by the earlier incidents), and end (solves the problem). Secondly, the plot maintains a unity in action bound together by internal necessity. Thirdly, plot must have what Aristotle calls a 'certain magnitude'. By this he means it is both quantitative (length and complexity) and qualitative (serious and universally significant). Fourthly, whilst a plot can be either simple or complex, the latter is better. She also notes, '[c]omplex plots have both "reversal of intention" (peripeteia) and "recognition" (anagnorisis) connected with the catastrophe. Both peripeteia and anagnorisis turn upon surprise' (McManus 1999a).

Regarding Aristotle's concept of magnitude, Pasala (2008:96) maintains that Aristotelian tragedy or drama is action characterised by unity and fullness, not by the scale of the work. Beginning, middle and end are essential for a unified work and are interdependent, connecting actions and consequences. 'Hence, the essential quality of drama is the consequential nature of events that give meaning to the multiple elements of a story' (ibid:96).

This flow is driven by the characters. Gustav Freytag (2008:22) sees three distinct qualities about the characters of a drama. Each character is related to the whole of the story, has a distinct personality, and the audience can identify with them. Freytag's pyramid gives a graphical illustration of how this works. This graphic illustrates elevated complication and emotional tension, culminating in the climax. The descending side of the pyramid depicts the decrease in tension and complication as the drama reaches its conclusion.

McManus (1999b) uses Freytag's pyramid to illustrate the unity of action in Oedipus Rex. In this structure, the causes and effects are stressed in the climax. Whilst not indicated in her chart, Oedipus demonstrates this concept of reversal by realising that he was the one who killed the king. This self-realisation ends with Oedipus sending himself into exile. 
Matthew's structure is built along the same lines. As in the example above, the plot is developed in conflict. This is no less true with Matthew, as his plot follows four types of conflicts with four different antagonists. Using Freytag's pyramid, the unity of action in Matthew builds a plot based on the conflict with primary characters in the book. These lead, as above in the unity of action in Oedipus Rex, to the climactic events of the death and resurrection. However, this climax was not the realisation of a fault or weakness. Rather, it was a reversal of the expected that elevated Jesus, thus validating Matthew's claim of Jesus as Messiah. Figure 1 demonstrates how Matthew's drama fits well into the Freytag pyramid.

Matthew's realisation comes in the resurrection that verifies and validates Jesus' divinity. Thus, to the benefit of his audience, his story is not dominated by Greek pessimism, which states, as Wright (2008:41) points out, as illustrated in Homer, that life after death is bleak. However, for Matthew, it is governed by the resurrection, avoiding catastrophe. This would align with Jewish expectations that Matthew represents so well. Levenson (2006:10) argues that, according to rabbinic tradition, resurrection permeates the Hebrew Bible. A primal insistence of that tradition is that resurrection is found in the Torah (Brueggemann 2007:31). Elsewhere, Levenson (2006:23) cites Midrash Sifre 32 as support for the frequency of the subject in the Hebrew writings. His contention is that scholars often 'lack the capacity to interpret properly'. In this chapter, he argues:

that within their own theological universe and their understanding of biblical interpretation, the rabbis had good reason to find resurrection in the Torah itself and, in doing so, they exposed some important aspects of biblical thought. (Levenson 2006:x)
As noted in the 'Unity of action in Matthew' (Figure 1), the climax is driven by the reaction of the Pharisees sending guards to the tomb. They were so concerned with Jesus' followers stealing the body and claiming a resurrection victory that they underestimated Jesus' promise to rise again. Satisfying this promise, Jesus turned the tables, validating his divinity, avoided catastrophe, and claimed absolute authority (Mt 28:18).

It is important to realise that growing the plot via various antagonists is not a straight, ascending cycle as the Freytag's pyramid pictures. The plot line, although ascending, should be visualised more like peaks and valleys of a large mountain than the steady climb up the side of a single hill. As Matthew leads us through this drama, each character encounter takes us to a height greater than the last. Yet, to get there, there is descent into peaceful ravines where Jesus takes time to talk with his followers about the events, giving the oracles of God to guide and comfort. Then, leaving this serene respite, the next peak must be conquered, offering vistas yet viewed that are more revealing than the last.

As demonstrated, storytelling is at the heart of the theatre. Oedipus's story is one of tragedy and deception. Matthew's gives hope that is not normally present in tragedy. The reason is that the second element of the theatre, imitation, is realised in Matthew's fulfilment motif that anticipates heroic expectations of the Jewish people - their Messiah. Jesus, the Deity or Hero (this is implicit in the titles given him son of David, son of Abraham, etc.) announces his destiny as he informs his disciples of his ultimate fate in Jerusalem (16:21). Matthew emphasises this by the use of $\delta \varepsilon \tilde{\imath}$ [it is necessary]. Arndt, Danker and Bauer (2000:214) note that this word carries the idea of compulsion based on a desired

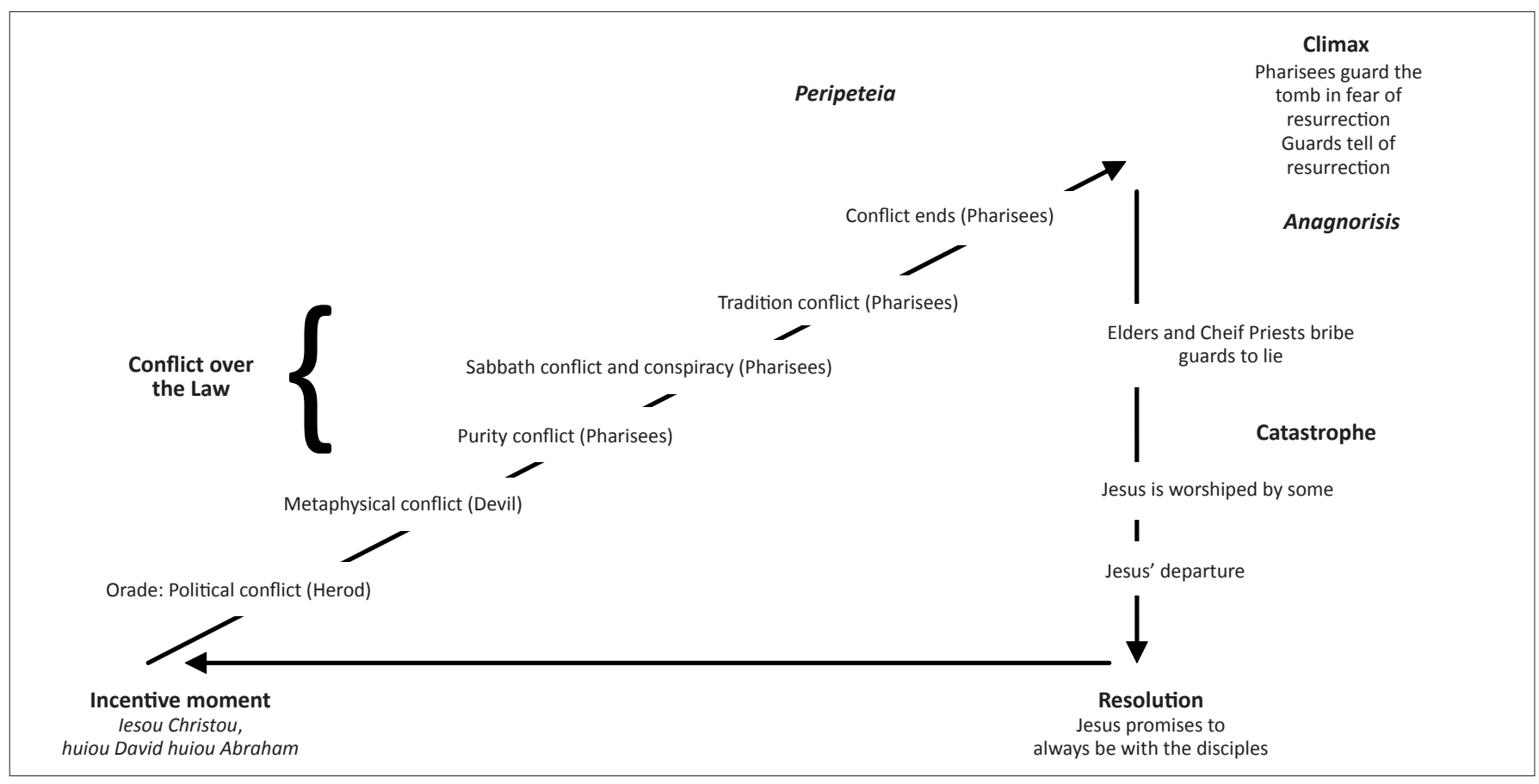

Author's adaption of the Freytag Pyramid.

FIGURE 1: Unity of action in Matthew. 
result. Grundmann (1964:21) expands this to understand that ' $[t]$ he term itself does not denote the authority which imparts this character. It is thus given its precise significance when conjoined with this power'. Matthew will later reveal - at the temple cleansing, 21:23-27 and on a Galilean mountain, 28:18 - the authority that is inherently Jesus', giving him the right to declare the divine necessity of his sacrifice. Matthew's hero is not doomed by this destiny, as in the Greek tragedy. Rather, there is a victory of resurrection that culminates in a continuation of the kingdom quest as evident by the command to make disciples. It is noteworthy that Campbell (1976:55) insists that resurrection is one of the common elements of the nature of gods and heroes. Campbell also notes (1990:127) that resurrection is a principle feature of the ritual for the hero. However, he implies it by stating that the body is not buried. In numerous illustrations from Greek mythologys (Oedipus, Theseus, Romulus, Heracles, Perseus, Jason, Zeus, etc.) and from biblical literature (Joseph, Moses, Elijah), or others such as Robin Hood, he demonstrates the patterns of the hero, giving points for each element of the pattern that they show. (By the way, Joseph scored only 12 points, but Moses scored 20 out of 22.)

\section{The antagonist}

Of course, every good story must have an antagonist. Matthew has several. This is not unusual, since the Greek actor may wear several masks, depicting several characters pertinent to the play. Originally, the play had only the chorus (50 people) and one actor. Later (525 BC), the chorus was reduced to 12 members, and a second actor was added. Sophocles (496-406 BC) adds a third actor and raises the chorus to 15 (Byrum n.d.; Stephens 2006).

In Matthew's drama, Jesus' antagonists, by order of appearance, are Herod (2:3, 12, 13, 16), the Devil (4:1), Pharisees (9:10-13), John's disciples (9:14-17), Sadducees (16:1-4), Peter (16:22-23), the priests and elders (21:23-27), and Pilate (27:2). Matthew builds his structure around conflict with these characters, setting the stage with them, climaxing in the discourses. As this develops, the reader will note that the characters, conversations, and events prior to the discourses are more than just narrative. Matthew is using the drama of life to set up the oracles of God given by Jesus. In Matthew's story, each of these sequences is essential to his climactic conclusion.

Blomberg (2001:25) supports this when he notes that the pairs of narrative/discourse develop a unified plot. This unified plot is not based on narrative. Rather, it is developed by the conflicts Matthew provides.

Why did Matthew choose to record only the conflicts?

It would seem to be more beneficial to present Jesus schooling the apostles, preparing them for ministry. Rather, he builds his story on conflict because conflict builds drama! Drama catches our attention. Thus, conflict makes us pay attention!
We analyse the conflict to see what caused it. Why did it develop? What is the solution? Matthew builds the drama, taking his audience into the very heart of Jesus' ministry. To understand his plot and his structure, it is necessary to examine the characters.

\section{The characters}

If Matthew's structure is to be properly determined, the characters are best studied as they appear in conflict with Jesus and Matthew's claim of Messiah, king (son of David), and covenant ideal (son of Abraham). Table 2 lists the primary conflicts in Matthew that have a direct bearing on his claims regarding Jesus.

There are two distinct groupings within the list of characters who serve as antagonists. Firstly, there are those who are aligned with Jesus but may not fully understand who he is or the significance of his mission. John's disciples and Peter form this group. As antagonist, they play a less significant role in the overall structure of the story. The remainder of the list given above forms the second group. Each of these fit into the historical drama of Jesus' life whilst adding both an actual and an allegorical significance to Matthew's work. The reason for this is that each of these characters helps advance the story that Matthew is telling. This is evident in that the accounts of John's disciples and Peter could have been omitted and the story would still have flowed as Matthew intended. However, such is not the case with the second group - the antagonists who are vital to the story. Had it not been for these, much of Matthew's reality would have been lost and the drama eliminated.

TABLE 2: Primary conflicts in Matthew.

\begin{tabular}{|c|c|c|}
\hline Character & Text & Detail \\
\hline Herod & $2: 3,12,13,16$ & Political (Jews \& Rome) \\
\hline Pharisees or Sadducees & $3: 7$ & Religious heritage \\
\hline Devil & $4: 1$ & Led to Satan by Holy Spirit \\
\hline Tempter & $4: 3$ & If or then ... Raising doubts \\
\hline Pharisees & $9: 10-13$ & Eating with sinners (Purity) \\
\hline Disciples of John & $9: 14-17$ & Fasting \\
\hline Pharisees & $9: 34$ & Jesus uses demons (Purity) \\
\hline Pharisees & $12: 2$ & $\begin{array}{l}\text { Criticise Jesus' disciples } \\
\text { (Sabbath) }\end{array}$ \\
\hline Pharisees & $12: 14$ & Conspired against him \\
\hline Pharisees & $12: 24$ & Casts out by Beelzebul \\
\hline Scribes or Pharisees & $12: 38$ & We want a sign \\
\hline Pharisees or Scribes & $15: 1-20$ & $\begin{array}{l}\text { Traditions of the elders } \\
\text { (Purity; not out or rather in) }\end{array}$ \\
\hline Pharisees or Sadducees & $16: 1-12$ & Sign from Heaven \\
\hline Peter & $16: 22-23$ & $\begin{array}{l}\text { Between Jesus and } \\
\text { Jerusalem }\end{array}$ \\
\hline Pharisees & $19: 1-12$ & Lawful to divorce \\
\hline Chief Priests or Elders & $21: 23-27$ & By what authority \\
\hline Chief Priests or Pharisees & $21: 45-46$ & Control Jesus; feared people \\
\hline Pharisees & $22: 15-22$ & Try to trap Jesus \\
\hline Sadducees & $22: 23-32$ & Resurrection question \\
\hline Pharisee (lawyer) & $22: 34-40$ & $\begin{array}{l}\text { Which is the greatest } \\
\text { commandment? }\end{array}$ \\
\hline Conflict ends & $22: 46$ & Could not answer a word \\
\hline Jesus retaliates! & $23: 13,15,23,25,27,29$ & Pharisees - Hypocrites \\
\hline Pharisees & $27: 62$ & Sealing the tomb \\
\hline
\end{tabular}




\section{Intentionality}

If speech acts (language communications that expect response) are indeed intended and this has always been human nature, then it is expected that the humans writing revelation would write with intention, such as, for example, to teach ( $R \mathrm{~m} \mathrm{15:4);} \mathrm{to} \mathrm{remind} \mathrm{(} R \mathrm{~m} \mathrm{15:15);} \mathrm{a} \mathrm{directive} \mathrm{(1}$ Cor 5:9); encouragement (1 Pt 5:12); to stimulate (2 Pt 3:1); blessings (Rv 1:3). For this, we would look at the writing and determine any or all intended messages possible in order to understand fully what the writer wanted us to know. We would depend on language for the meaning to be clear, concise, and understandable. This is the purpose of language.

The examination made of Matthew's literary style (written communication), has revealed certain characteristics that bear a marked resemblance to the structure of a Greek play. Whilst Matthew did not directly tell his readers that this was written in this manner, does this guarantee that he did not? Is it possible that Matthew intended for his readers to naturally recognise these characteristics?

Intentionality that is not expressed may be realised in the non-natural meaning, that is, the meaning outside of the natural. ${ }^{1}$ The argument reads:

$S$ non-naturally means something by an utterance $x$ if $S$ intends $\left(i_{1}\right)$ to produce by uttering $x$ a certain response $(r)$ in an audience $A$ and intends $\left(i_{2}\right)$ that $A$ shall recognise $S$ 's intention $\left(i_{1}\right)$ and intends $\left(i_{3}\right)$ that this recognition on the part of $A$ of $S$ 's intention $\left(i_{1}\right)$ shall function as $A^{\prime}$ s reason or a part of his reason, for his response $r$. (Strawson 2008:341)

This can be worked out in Matthew by the following:

Matthew (and/or his editor[s]) non-naturally means something by a literary style that produces a natural break in his work (Kaì $\dot{\varepsilon} \gamma \varepsilon \dot{\varepsilon \varepsilon} \tau$ ö $\tau \varepsilon \dot{\varepsilon} \tau \dot{\lambda} \lambda \varepsilon \sigma \varepsilon v$ [And when \{Jesus\} finished] - 7:28; 11:1; 13:53; 19:1; 26:1 - and Aлò тó $\varepsilon$ [from then] - 4:17; 16:21). If he (Matthew and/or his editor[s]) intends $\left(i_{1}\right)$ to produce, by using these literary marks, a certain response $(r)$, i.e., understanding the universality of his work and intends $\left(i_{2}\right)$ that the readers shall recognise his (Matthew and/or his editor[s]) intention $\left(i_{1}\right)$ and (Matthew and/or his editor[s]) intends $\left(i_{3}\right)$ that this recognition on the part of the readers of the writer's intention $\left(i_{1}\right)$ shall function as the communities reason, or a part of their reason, for their response $(r)$.

From this argument, three intentions are realised:

$\left(i_{1}\right)$ The author's intention in writing to the church community

$\left(i_{2}\right)$ The author's hopes that the church realises his intentions after reading the narrative

$\left(i_{3}\right) \quad$ The author's hope that the church's recognition of the original intention will be the reason or part of the reason for responding to the teaching the way the author hoped

Strawson (2008:346) further suggests another intention $\left(i_{4}\right)$. He suggests that if both $S$ (Matthew (and editor[s]) and $A$ (and the church) were well aware of $S$ 's (Matthew and editor[s]) first two intentions $\left(i_{1}\right)$ and $\left(i_{2}\right)$, then the fourth intention $\left(i_{4}\right)$ is that Matthew and/or editor(s) desired that the readers understood both what was intended to be communicated by the literary devices and that he intended that they would produce the desired result. What is said about these can also be said about the characters and their relationship to the narrative, as well as any other literary feature used by the author or editor(s).

Thus, the intentions may be obvious in that the structure, having semblance to a Greek drama, uses a common, wellknown medium to convey his important message. From this, the intention would be to show the universality of the message and this writing as an appropriate means of conveying the message universally. When this takes into consideration the way characters are introduced and interact, the intentionality may become even more obvious.

\section{Conclusion}

This study offers evidence that the author or editor(s) intentionally structured the gospel with definite literary markers. These markers, when considered with the flow, the characters, and the surprising reversal (resurrection and a universal mission), bear a strong semblance to a Greek drama. This gives reason to suspect that the author or editor(s) may have intentionally orchestrated the book as a drama with the intent of having an understandable, attractive way to present Jesus to Jew and gentile alike. For some, this may distract from the Jewishness of the gospel. However, Jews, particularly Hellenised Jews, were also attracted to the theatre.

Blending the ideas of a Greek drama with the Jewish nature of the book raises the question as to why use a Greek literary genre to defend the position of Jesus as the Christ, son of David, son of Abraham. Whilst there were Jews in his community, his universal appeal proposes that his intent is not limited just to the Jews. Rather, his intentions are to maintain the integrity of the Jewish heritage of Christianity. After all, Jesus was a Messiah promised to the Jews whose


the ethnics (nations)] (Mt 28:19).

\section{Acknowledgements Competing interests}

The authors declare that they have no financial or personal relationship(s) that may have inappropriately influenced them in writing this article.

\section{Authors' contributions}

C.W. (North-West University) and F.P.V. (North-West University) supervised P.R.M. (North-West University) in his research and writing of the article.

\section{References}

Aristotle, 350 BCE, 'Poetics', transl. S.H. Butcher, in classics.mit.edu, viewed 07 June 2013, from http://classics.mit.edu/Aristotle/poetics.html

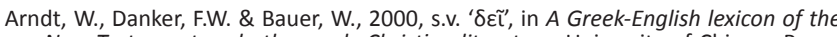
New Testament and other early Christian literature, University of Chicago Press, Chicago, IL, 3rd edn., p. 214.

Aune, D.E., 1987, The New Testament in its literary environment, Westminster, Philadelphia, PA. 
Baldwin, B., 1979, 'Biography at Rome', Studies in Latin Literature and Roman History $1,110-118$

Barclay, J.M.G., 1996, Jews in the Mediterranean diaspora: From Alexander to Trajan (323 BCE-117 CE), T\&T Clark, Edinburgh.

Blomberg, C., 2001, Matthew, Broadman \& Holman, Nashville, TN

Brueggemann, W., 2007, 'Jews and Resurrection, ultimate victory', Christian Century 124(3), 31-33.

Burian, P. \& Shapiro, A., 2008, The complete Sophocles: Electra and other plays, vol. II, Oxford University Press New York, NY.

Burridge, R.A., 1995, What are the Gospels?: A comparison with Graeco-Roman biography, Cambridge University Press, Cambridge.

Byrum, N.R., n.d., 'Timeline: Development of Greek drama', in Timeline developmen of Greek drama, viewed 16 September 2011, from http://english.tjc.edu/ engl2332nbyr/Greektheatertimeline.htm

Campbell, J., 1968, The hero with a thousand faces, Princeton University Press, Princeton, NJ.

Campbell, J., 1976, The masks of God: primitive mythology, Penguin Books, Harmondsworth, Middlesex.

Campbell, J., 1990, In quest of the hero, Princeton University Press, Princeton, NJ.

Campbell, J. \& Moyers, B., 1988, The power of myth, Doubleday, New York, NY.

Chatman, S.B., 1978, Story and discourse: Narrative structure in fiction and film, Cornell University Press, Ithaca, NY.

Cook, R.M.J., 2008, Modern Jews engage the New Testament, Jewish Lights, Woodstock, VT.

Csapo, E. \& Slater, W., 2005, 'Greek theatre, ancient', in D. Kennedy (ed.), The Oxford encyclopedia of theatre and performance, viewed 27 September 2011, from http:// encyclopedia of theatre and performance, viewed 27 September 2011, from http:// wWw. oxfordreference.com/view/10.1093/acref/97801986

Deissman, A., 1910, Light from the Ancient East, Hodder and Stoughton, New York, NY.

Dunn, J.D.G., 2005, A new perspective on Jesus: What the quest for the historical Jesus missed, Baker Academic, Grand Rapids, MI.

Elliott, M.A., 1992, 'Israel', in J.B. Green \& S. McKnight (eds.), Dictionary of Jesus and the Gospels, Intervarsity Press, Downers Grove, IL.

Englert, W., 2012, 'Ancient Greek theater', in academic.reed.edu, viewed 16 September 2011, from http://academic.reed.edu/humanities/110tech/theater.html

Foley, H.P., 2010, 'Tragedy, Greek', in M. Gagarin (ed.), The Oxford encyclopedia of Ancient Greece and Rome, viewed 29 September 2011, from http:// www.oxfordreference.com/view/10.1093/acref/9780195170726.001.0001/ acref-9780195170726

Free, K.B., 1999, 'Thespis and Moses: The Jews and the Ancient Greek Theatre', in S. Levy (ed.), Theatre and Holy Script, p. 150, Sussex Academic Press, Brighton.

Freytag, G., 2008, Freytag's technique of the drama: An exposition of dramatic composition and art, BiblioBazaar, LLC, Charleston, SC.

Gardner, R.B., 1991, Matthew, Herald Press, Scottdale, PA.

Geiger, J., 1985, Cornelius Nepos and ancient political biography, Franz Steiner, Stuttgart.

Goranson, S., (2007), 'Celsus of Pergamum: Locating a critic of early Christianity', in D.R. Edwards \& C.T. McCollough (eds.), The archaeology of difference: Gender, ethnicity, class and the 'other' in antiquity studies in honor of Eric M. Meyers, pp. 363-364, American Schools of Oriental Research, Boston, MA.

Grice, H. P., 1957, 'Meaning', The Philosophical Review 66(3), 377-388.

Grundmann, W., 1964, s.v. ' $\delta \varepsilon \tilde{\imath}$ ', in G. Kittel, G.W. Bromiley \& G. Friedrich, (eds.), Theological dictionary of the New Testament, Eerdmans Grand Rapids, MI, electronic edn., p. 21.

Guthrie, D., 1990, New Testament introduction, InterVarsity Press, Downers Grove, IL.

Hendriksen, W. \& Kistemaker, S.J., (1953-2001), New Testament commentary: Exposition of the Gospel according to Matthew. New Testament commentary, Baker Book House, Grand Rapids, MI.
Kingsbury, J.D., 1988, Matthew as story, 2nd edn., Fortress Press, Philadelphia, PA.

Levenson, J.D., 2006, Resurrection and the restoration of Israel: The ultimate victory of the God of life, Yale University Press, New Haven, CT.

Luz, U., 2005, Matthew 21-28, Fortress Press, Minneapolis, MN.

MacLennan, B., 1999, 'Typical structure of a Greek play', in web.eecs.utk.edu, viewed 22 September 2011, from http://web.eecs.utk.edu/ mclennan/Classes/US210/ Greek-play.html

McManus, B.F., 1999a, 'Outline of Aristotle's theory of tragedy', in Poetics, viewed 27 September 2011, from http://www2.cnr.edu/home/bmcmanus/poetics.html

McManus, B.F., 1999b, 'Plot Structure in Oedipus Rex', viewed 6 April 2014, from http://www2.cnr.edu/home/bmcmanus/oedipusplot.html

Momigliano, A., 1971, The development of Greek biography, Harvard University Press, Cambridge, MA.

Nolland, J., 2005, The Gospel of Matthew: A commentary on the Greek text, Eerdmans, Grand Rapids, MI.

Pasala, S., 2008, The drama of the Messiah in Matthew 8 and 9: A study from a communicative perspective, Bern, New York, NY.

Risley, J.F., 2009, 'Who are You, Lord?', in Knowing Jesus and his friends better viewed 18 December 2011, from http://jeanrisley.com/Who/articles/ WhoArtLukesGospel.htm

Robinson, S.R., 2002, 'Theatre and drama in ancient Greece', in www.cwu.edu, viewed 03 January 2014, from http://www.cwu.edu/ robinsos/ppages/resources/ Theatre_History/Theahis_2.html

Russell, D.A., 1972, Plutarch, Duckworth, London.

Shuler, P.L., 1982, A genre for the Gospels: The biographical character of Matthew, Fortress, Philadelphia, PA.

Sophocles, 2010, Ajax, Richer Resources Publications, Arlington, VA.

Stanton, G., 1993, A Gospel for a new people: Studies in Matthew, Westminster/John Knox Press, Louisville, KY.

Stauffer, E., 1964, s.v. 'egō', in G. Kittel, G.W. Bromiley \& G.F. Kittel (eds.), Theological dictionary of the New Testament, Eerdmans, Grand Rapids, MI, electronic edn., p. 54.

Stein, R.H., 2001, Studying the synoptic Gospels: origin and interpretation, 2nd edn., Baker Academic, Grand Rapids, Ml.

Smith, J., 2006, Ancient Greek Theatre, PowerPoint Presentation, California State University, San Bernadine, CA

Strawson, P.F., 2008, 'Speech acts and speaker meaning', in S. Nuccetelli \& G. Seay (eds.), Philosophy of language: The central topics, pp. 341, 346, Rowman \& Littlefield, Plymouth.

Talbert, C.H., 1993, 'What are the Gospels: a comparison with Graeco-Roman biography', Journal of Biblical Literature 112(4), 714-715. http://dx.doi. biography', Journal
org/10.2307/3267416

Trumbull, E.W., 2007, 'Ancient Greek theatre', in Introduction to theatre online course, viewed 16 September 2011, from http://novaonline.nvcc.edu/eli/spd130et/ viewed 16 September

Utley, R.J., 2000, The first Christian primer: Matthew, Bible Lessons International, Marshall, TX.

Walvoord, J. F., Zuck, R. B. \& Dallas Theological Seminary, 1985, The Bible knowledge commentary: An exposition of the Scriptures, Electronic edn., Victor Books, Wheaton, IL.

Weber, S.K., 2000, Matthew, vol. 1, Broadman \& Holman Publishers, Nashville, TN. (Holman New Testament Commentary).

Webster, M., 2004, 'Tragedy: The basics', in faculty.gvsu.edu, viewed 16 September 2011, from http://faculty.gvsu.edu/websterm/Tragedy.htm

Wiemelt, J., n.d., 'The classical Greek chorus', in selu.edu, viewed 22 September 2011 , from http://www2.southeastern.edu/Academics/Faculty/jwiemelt/classes/ engl230/chorus.htm

Wright, N.T., 2008, 'Jesus' resurrection \& Christian origins', Stimulus 16(1), 41-50. 